\title{
使用済み制御棒の減容処理に伴う内包物 $B_{4} C$ 粉体の拡散防止技術の開発
}

\section{舘村誠*1 遠藤智尋*2 板垣昌利*2 黒澤良樹*3 山井英樹*2 米谷豊*2 増田稔*2}

使用済み制御棒は中深度処分の対象として埋設処分を計画している. 制御棒は長さ約 $4 \mathrm{~m}$ に対し, 中深度処分容器は 1 辺 $1.6 \mathrm{~m}$ 立方体の大きさであるため, 使用済み制御棒の減容には切断処理が必要となる。一方，使用済み制御棒を短 冊に切断するとその内包物である $\mathrm{B}_{4} \mathrm{C}$ 粉体が水中へ拡散し, 污染の拡大とその 2 次処理負担の増加が生じる. さらに その対策に有効な切断技術が確立されていない。 そこで内包物の拡散防止を目的にプレスと水中プラズマ溶断を組み合 わせた切断技術を提案し検討してきた. 本研究では実際の制御棒と同じ垂直姿勢で水中切断実験を行い, 水中に拡散し た $\mathrm{B}_{4} \mathrm{C}$ 粉体量の分析を行い, その拡散防止の効果を評価した. その結果, 短冊片に浸入する水分量は, 制御棒 1 体当たり $52.8 \mathrm{mg}$ と乾燥処理に影響しない大きさであった. 短冊片に切断したときに水中へ拡散した $\mathrm{B}_{4} \mathrm{C}$ 粉体量は, 制御棒 1 体当 たり $3.6 \mathrm{~g}$ で，制御棒 1 体から水中に拡散する $\mathrm{B}_{4} \mathrm{C}$ 粉体の割合は $0.05 \%$ と僅かで，本手法は $\mathrm{B}_{4} \mathrm{C}$ 粉体の拡散防止に効果 があることが確認できた。

\section{Keywords: 減容, 使用斉み制御棒， $\mathrm{B}_{4} \mathrm{C}$ 粉体，水中プラズマ溶断}

The spent control rod assemblies are to be processed as a waste for an underground disposal (depth $\geq 70 \mathrm{~m}$ ). The spent control rod assemblies ( $4 \mathrm{~m}$ in length) need to be cut into 4 sections in order to be stored in the storage containers $(1.6 \mathrm{~m} \mathrm{x} 1.6 \mathrm{~m} \mathrm{x} 1.6 \mathrm{~m})$. When the control rod is cut, the $\mathrm{B}_{4} \mathrm{C}$ powder contained inside the rod is leaked into the water. Contaminating the surrounding water would increase the secondary treatment cost, and consequently the overall processing cost.

In this study, we examined a cutting technology that combines press working and underwater plasma cutting, in order to seal the cut control rods and prevent the $\mathrm{B}_{4} \mathrm{C}$ from being scattered into the water. We cut the control rods underwater in a vertical upright position, and confirmed the effects of $\mathrm{B}_{4} \mathrm{C}$ scattering.

After cutting, the water ingress of the neutron absorbers was $52.8 \mathrm{mg}$ per control rod. The $\mathrm{B}_{4} \mathrm{C}$ leaked during cutting was 3.6 g. The ratio diffuse of $\mathrm{B}_{4} \mathrm{C}$ from per control rod was $0.05 \%$. In conclusion, the results showed that the cutting technology used in this study is effective, and the $\mathrm{B}_{4} \mathrm{C}$ can be reduced considerably during processing.

Keywords: volume reduction, spent control rod, $\mathrm{B}_{4} \mathrm{C}$ powders, underwater plasma cutting

\section{1 緒言}

原子力発電所が運用し始めてからおよそ半世紀が過ぎ, 高経年化に伴って必要な対策を講じるか, 廃炉に踏み切る かの検討がなされている $[1,2]$. 放射性廃棄物の処理に関し 恒久的な措置の正式決定はまだであるが，低レベルの放射 性廃棄物では, 放射性物質の種類や放射能レベルによって 区分し，区分に応じて埋設する深さを変えるなどの処分計 画が進められている[3].

制御棒は燃料からの中性子を吸収する能力があり，燃料 集合体からの出し入れにより発電の出力調整を担う。所定 の中性子照射量を吸収し，役割を終えた制御棒は新品へと 交換され，使用済み制御棒として原子炉内の貯蔵プール内 で保管される，最終的に使用済み制御棒は，低レベルの放 射性廃棄物 L1 として深度 $70 \mathrm{~m}$ 以上の中深度で処分する計 画である.中深度で処分する収納容器の大きさは 1 辺 $1.6 \mathrm{~m}$ の立方体の箱の中に廃棄物を収納し, 深度 $70 \mathrm{~m}$ 以上の処 分施設に埋設する[3].

埋設する収納容器の数量は，処分施設の地下埋設スペー スの大きさ，地下掘削の資源環境への影響，埋設に関連す る作業量，人員および資源エネルギー消費の大きさに影響 を与える数值である. 収納容器の発生個数の削減は, 処分

\footnotetext{
Development of a technique preventing $\mathrm{B}_{4} \mathrm{C}$ diffusion during size reduction of spent control rods. by Makoto TATEMURA (makoto.tatemura.tx@ hitachi.com), Tomohiro ENDO, Masatoshi ITAGAKI, Yoshiki KUROSAWA, Hideki YAMAI, Yutaka KOMETANI and Minoru MASUDA

*1 株式会社日立製作所 研究開発グループ Hitachi, Ltd. Research \& Development Group 厂244-0817 神奈川県横浜市户塚区吉田町 292

*2 日立 $\mathrm{GE}$ ニュークリア・エナジー株式会社 Hitachi-GE Nuclear Energy, Ltd. 干319-1221 茨城県日立市大多加町 5-2-2

*3 株式会社日立アーバンインベストメント Hitachi Urban Investment, Ltd. 干 244-0817 神奈川県横浜市戸塚区吉田町 292 (Received 31 January 2019; accepted 17 May 2019)
}

施設の規模縮小化に反映され，環境への負担抑制と廃炉コ ス卜低減の両立に繋がる。一方で廃棄物は所定量があり, 収納容器の発生個数を削減するには，所定量の廃棄体を効 率良く収納することが重要となる.

本研究は, 収納効率を向上させるための要素技術として, 使用済み制御棒の解体について着目し検討することにした。 沸騰水型原子炉 (BWR) の制御棒は $4 \mathrm{~m}$ 程の長さであるが, 1 辺 $1.6 \mathrm{~m}$ の収納容器へ効率よく収納するには, 4 分の 1 程 度へ短冊片に分割する必要がある。制御棒の材料である中 性子吸収材は主に炭化ホウ素，あるいは八フニウムが用い られている．国内の原子炉運用初期段階から使用されてい る炭化ホウ素粉体 (以下, $\mathrm{B}_{4} \mathrm{C}$ 粉体) から成る制御棒では, その使用済み制御棒を短冊に切断した場合，切断面から放 射化した $\mathrm{B}_{4} \mathrm{C}$ 粉体が水中へと拡散される.

海外の廃炉に関し, BWR 型の炉内構造物（制御棒含む） の解体は，ディスクソーまたはバンドソーの機械式切断で 水中解体作業を実施しており [4], 結果として $\mathrm{B}_{4} \mathrm{C}$ 粉体が水 中へ拡散する状況でも廃棄物の処理は行われている.

しかし，水中拡散した粉体はそのままでは周囲への污染 が広がるため，粉体の拡散を防ぎ捕集を行う回収設備を設 けることになる. 回収設備には粉体をフィルタで吸着する 機構を設けるが，発生する粉体の数量が多い場合，回収設 備の機構は大きくなり，さらに吸着で污染したフィルタの 数量も増加する. そして, 2 次処理分の収納容器の数量が 増え, 原子炉設備内の 2 次処理費用の増加と, 収納容器の 数量増による処分施設の規模拡大となり, 環境への影響と コスト負担が大きくなる（Fig.1）.

以上の背景から使用済み制御棒の解体とその収納では, 収納効率が高く，且つ周囲の環境に影響を及ぼさないこと が重要と捉え，それらの両立を達成するには例えば短冊に 切断したときに $\mathrm{B}_{4} \mathrm{C}$ 粉体が水中へ拡散しないような切断方 


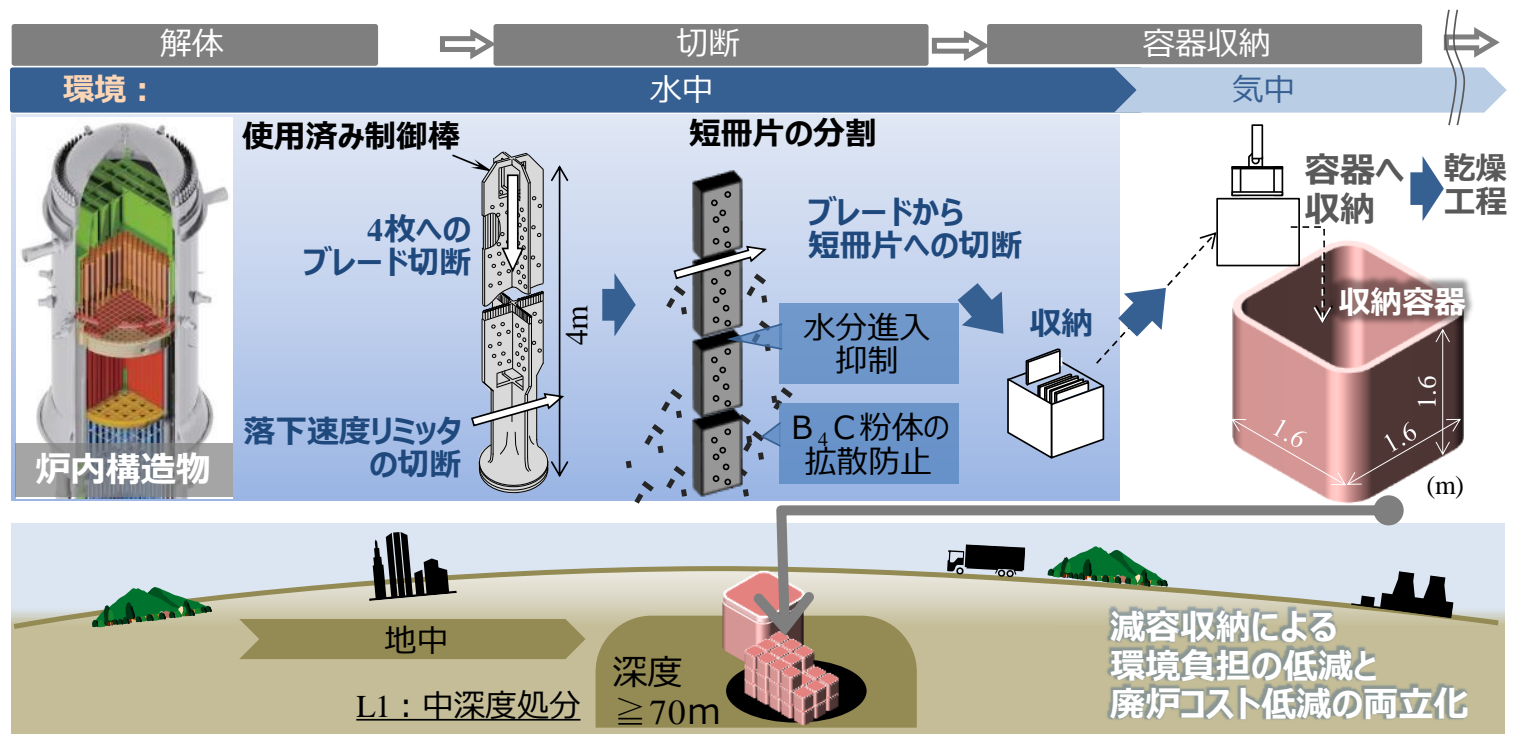

Fig.1 Decommissioning process of spent control rods

法が必要であると考えた.

本報告では，使用済み制御棒の減容に関し， $\mathrm{B}_{4} \mathrm{C}$ 粉体の 拡散を防止することを目的に，制御棒の切断方法について 検討した結果を報告する。

\section{2 技術課題}

\section{1 制御棒の減容方法}

本研究は使用済み制御棒に内在する $\mathrm{B}_{4} \mathrm{C}$ 粉体の拡散を防 ぎながら切断する工法の開発が目的である。その代表的な 制御棒の概略図を Fig.2 に示す。制御棒の外観は全長 $4 \mathrm{~m}$ 程で，ブレード 4 枚を十字形に配置した構成である．その ブレードには表側のステンレス板（以下，シース）の内側 に, 中性子吸収棒が約 20 本一列に並べられている. 中性子 吸収棒のステンレス鋼管には，中性子を吸収する $\mathrm{B}_{4} \mathrm{C}$ 紛体 (粒径数マイクロメートル〜数ミリメートル) が約 $70 \%$ の 充填率で詰められている. 4 枚のブレードは外側のシース 端之十字断面の中央にあるステンレス素材のブロック材 (以下，タイロッド）を溶接して十字形に固定している.

使用済み制御棒を減容収納する場合，いくつかの方法が 考えられるが，ここでは収納効率が高い減容方法を例に説 明する。はじめに，制御棒の下部にある落下速度リミッタ 部位を水中プラズマ切断，あるいはワイヤーソーなどの金 属板を解体する方法で切断する．分離後の落下速度リミッ 夕部位は別の容器に集めて収納する. 次に十字形断面のブ レード 4 枚の構造物について，その十字形の根元にある夕 イロッド部分を図中の縦方向に切断（ブレードへの切断） し， 4 枚のブレード（長さ $4 \mathrm{~m}$ ） 八分割する. 最後は，収 納容器に収めるため，4 枚のブレードをそれぞれ 4 分割の 短冊片（長さ $1 \mathrm{~m} /$ 片）へと切断寸る。なお，使用済み制御 棒は放射化しており，その取り扱いはすべて水中で遠隔操 作により実施される。このような切断で収納した場合，1 つの収納容器（1.6 m 角形状）には，使用済夕制御棒を 50 $\sim 80$ 体（占有率 $70 \%$ 以下）の収納が可能となる.

前述の短冊切断への工程では，各ブレードの中性子吸収
棒を横切って切断するため, その内包物である $\mathrm{B}_{4} \mathrm{C}$ 粉体が 水中へと拡散される.放射化した $\mathrm{B}_{4} \mathrm{C}$ 粉体の拡散は 2 次処 理負担の増加に至る.一方で, 切断された短冊片 (約 $1 \mathrm{~m}$ ) の切断面は水中に暴露されているため，短冊片内に水が浸 入することになる. 水の浸入によって短冊片内の $\mathrm{B}_{4} \mathrm{C}$ 粉体 は水を吸収しペースト状となる。

なお，通常 L1 廃棄物は水中で解体し所定の容器一収納 する．水分を多く含む放射化した廃棄物をそのまま収納容 器に入れて長期間保管すると, 水の放射線分解により, 時 間経過とともに水素ガスが発生することが考えられる．原 子力規制委員会では，中深度処分を行う場合に当たって，

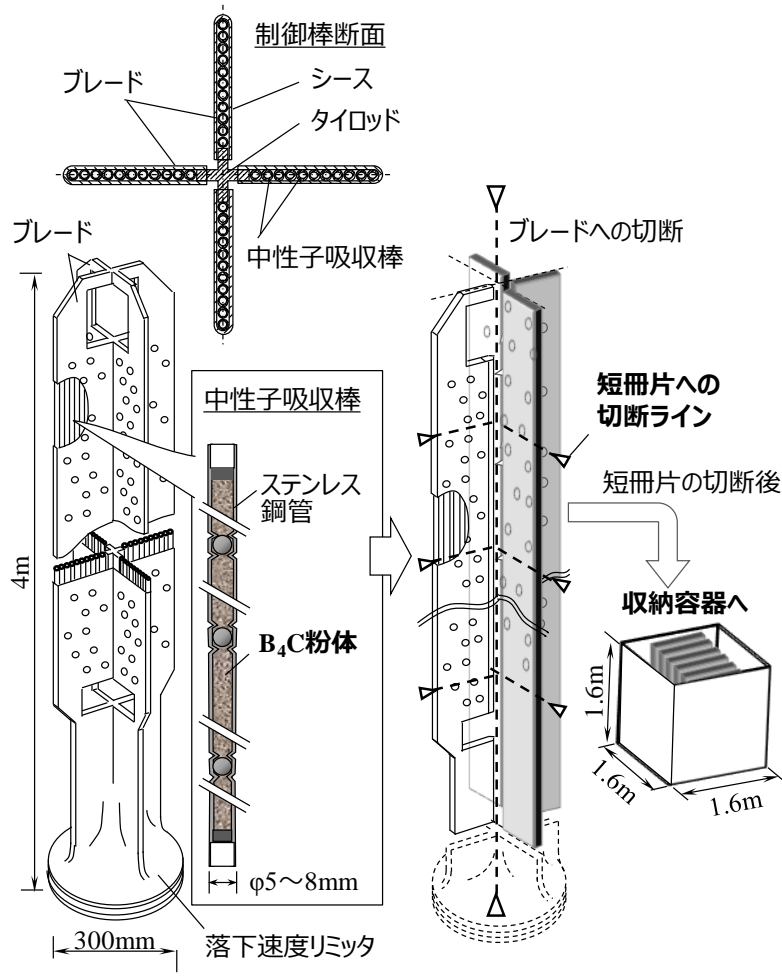
(a) 制御棒
(b) 解体の流れ

Fig.2 Control rod structure and cutting process 
廃棄体の健全性および廃棄物埋設地の安全機能が損なわれ ることがないよう廃棄体中の水素の発生を抑制する等の措 置が講じられていることを規定[3]しており，長期間保管時 のガス発生を抑えるために廃棄物を収納容器に入れた後, 大気中に取り出して乾燥処理を行い，余分な水分を飛ばし た後に容器を密閉し, 中深度（深度 $70 \mathrm{~m}$ 以上） 一埋設す る計画である。

一般方法で短冊片に切断するとペースト状の水分を多く 含み, その後の乾燥工程での処理設備と処理時間が増大し, 設備費用およびランニングコストがかさむ.

以上より，使用済み制御棒の減容収納の課題は，短冊に 切断したときに $\mathrm{B}_{4} \mathrm{C}$ 粉体などの内包物を拡散させず,かつ, 解体後の短冊片に水分浸入を抑制した減容収納ができる手 法を開発することであり，本研究はその課題を解決するた めの検討を行った。

\section{2 事前検討}

使用済み制御棒内の $\mathrm{B}_{4} \mathrm{C}$ 粉体を拡散させずに切断が可能



1 つ目は切断箇所をプレスしながら押しつぶし，そのま ま， $\mathrm{B}_{4} \mathrm{C}$ 粉体が内在しているステンレス鋼管の口を閉じて 押し切る，あるいはかしめを組み合わせて押し切る方法で ある．結論から述べると，押し切ったステンレス鋼管の切 断面は，鋼管の口を完全に閉ざすことが困難で，鋼管の口 は $1 \mathrm{~mm}$ ほど開いた格好で切断されることがわかった。理 由は，鋼管の内側に充填率 $70 \%$ で詰められている $\mathrm{B}_{4} \mathrm{C}$ 粉 体がダイヤモンド並みに硬く（ビッカース硬度 : $33 \mathrm{GPa}$ ), プレスで押しつぶしても，鋼管のステンレス鋼のみが破断 し $\mathrm{B}_{4} \mathrm{C}$ 粉体自体は粉砕されない。粉体の粒径は，大きいも のは 1〜2 mm 程度で, $\mathrm{B}_{4} \mathrm{C}$ 粉体の粒径を維持したまま鋼管 を押し切ると，1〜2 $\mathrm{mm}$ 程度の隙間が空いて切断されるこ とになる。

したがってプレスで押しつぶす，またはかしめを組み合 わせたプレスで切断する方法で口を閉じることは，原理的 に困難と判断した。

2 つ目は，高温のガスを吹き付けて金属を溶かしつつ， 噴出ガスの勢いで溶けた金属を吹き飛ばして切断する水中 プラズマ切断を用いた方法である. 手塚ら[5]は，東京電力 福島第一原子力発電所において 2012 年度より 3 力年の切断 試験を通じて水中切断が可能なプラズマ切断技術の開発を 進め，炉内構造物等の取出しに有効な工法であることを報 告しており，我々は上述の水中プラズマ切断手法を基本に 検討することにした。

ただし，水中プラズマ切断の通常の切断条件では，使用 済み制御棒の切断面はシャープな切断面が形成され，制御 棒の内側が暴露され $\mathrm{B}_{4} \mathrm{C}$ 粉体が水中へ拡散してしまうこと が予想される。中性子照射を受けたステンレス鋼を扱う加 エプロセスに関し，溶接プロセスあるいはプレス加工の成 立性を検討し [6,7]，切断箇所の溶融と固着のプロセスを調 整することで切断面の口を塞ぐ技術開発を進めた。その結 果, 溶融に必要な水中プラズマ加工条件と, 切断面を封止 しやすくするために，予め切断面を薄くするプレス加工の 施策（切断箇所を予めプレスして薄くし溶融物が覆いやす
くする）を組み合わせた手法が有効であることがわかった. 例えばプレスする前は切断箇所に占めるステンレス材と $\mathrm{B}_{4} \mathrm{C}$ 粉体の比率は $\mathrm{B}_{4} \mathrm{C}$ 粉体の方が多く切断面を溶着物で塞 ぎにくいが，切断箇所を事前にプレスし，切断箇所の断面 に占める比率がステンレス材の方を多くすることで，切断 面はステンレス材の溶着物で封止しやすくなる．プレスの 圧縮率を調整することで，その後のプラズマ照射により切 断面を溶着できる見込みが得られたと考えた.

以上の結果， 2 つ目の方法であるプレス加工と水中プラ ズマ加工（以下，水中プラズマ溶断）の組み合わせを用い た $\mathrm{B}_{4} \mathrm{C}$ 粉体拡散防止の切断技術の開発を行うこととした. その切断手法は以下の流れで行う（Fig.3）.

(1) 切断予定箇所をパンチでプレスして凹ませる.

(2) 凹み箇所にプラズマアークを照射し, 照射表面のステ ンレス鋼を溶融しながら切断（溶断）する。

(3) 切断面には周囲の水で冷却された溶着物で塞ぎ, $\mathrm{B}_{4} \mathrm{C}$ 粉体の拡散と短冊片への水分浸入を防止する.

本報告は，プレス加工と水中プラズマ溶断を用いた水中 短冊切断における $\mathrm{B}_{4} \mathrm{C}$ 粉体の水中拡散防止技術の妥当性評 価を目的に， $\mathrm{B}_{4} \mathrm{C}$ 粉体の水中拡散量，短冊片への水分浸入 量, 切断時オフガス発生量を定量評価した結果を報告する.

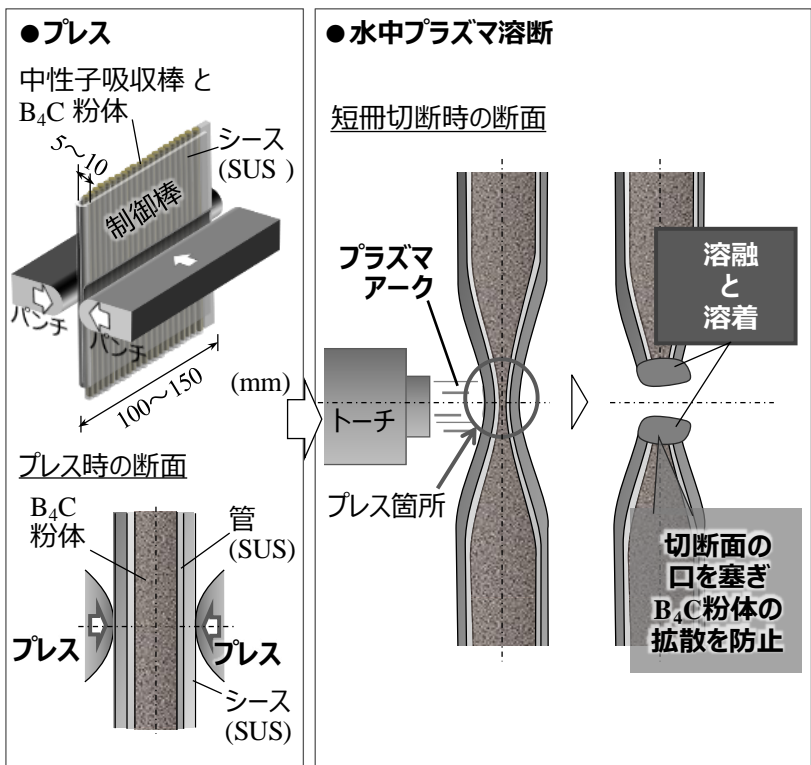

Fig.3 Cutting and sealing process of control rod blades

\section{$3 \mathrm{~B}_{4} \mathrm{C}$ 粉体の拡散防止切断条件の検討}

\section{1 試験体}

プレス加工とプラズマ溶断を組み合わせた切断条件の検 討を目的に, Fig.4 に示寸制御棒を模擬した試験体を製作し 実験を行った．試験体には実際の制御棒へ組み込む未使用 の中性子吸収棒 5 本 $\left(\mathrm{B}_{4} \mathrm{C}\right.$ 粉体の充填率 $70 \%$ ）を用い，ブ レードを模擬したシース部位とタイロッド部位を溶接し組 み立てた。プレス箇所は図に示すように中性子吸収棒を横 切る配置とし，製作した試験体 1 体につき数箇所プレスし た. 


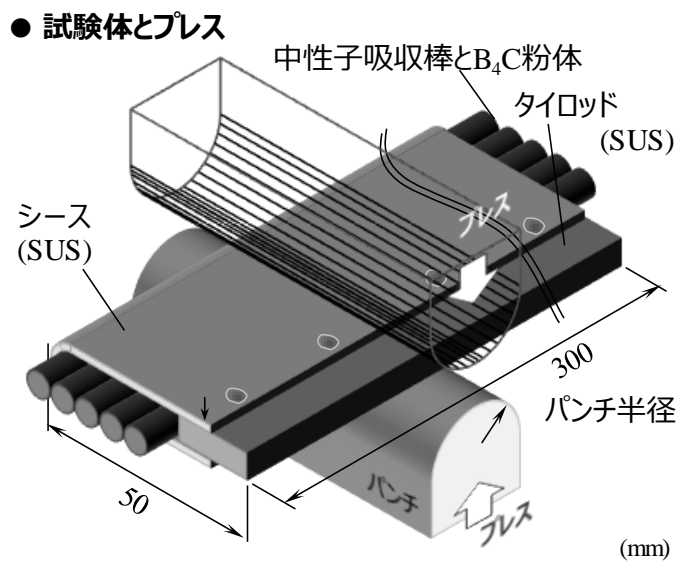

Fig.4 Press working of the test piece

\section{2 プレス条件の検討}

Fig.5 に試験体にプレスしたときの外観の様子とその切 断面を示す. 中性子吸収棒を横切る位置にタイロッドごと プレスされた痕が見られる. プレス箇所の断面は元の厚さ に比べ半分程度に潰れ，元の形状が円管であった中性子吸 収棒管は矩形へと変形していることが確認できた。プレス で潰れた断面は $\mathrm{B}_{4} \mathrm{C}$ 粉体が占める面積に比べ，ステンレス 材の方がその割合が多かった。切断面を塞ぐ役割があるス テンレス材の方が $\mathrm{B}_{4} \mathrm{C}$ 粉体に比べ占有面積が多いことは切 断面を封止しやすくする 1 つの条件と考える.



Fig.5 Test piece after press working

プレス条件の検討を目的に, 3 種類のパンチ半径 $(6,8,10$ $\mathrm{mm}$ ）を用いて検討した．実験に用いたプレス機は縦型サ ーボプレス機（アマダ製 : SDE1522，1500 kN）である.プ レスで潰した圧縮比とその後の溶断による溶着物の封止の 良し悪しの関係を明らかにするため，事前検討で得た封止 が可能な水中プラズマ溶断条件を用いて，圧縮比の違いに よる封止可否を評価した。

Fig.6 にパンチ半径当たりのプレス荷重とプレス後の圧 縮比（プレス圧縮比）の関係について示し，その後の溶断
による切断面の封止可否を図中に示す.

パンチ半径当たりのプレス荷重が高くなるとともにプレ ス圧縮比は直線的に減少し, プレス圧縮比約 0.66 を境に, 切断面の封止可否が分かれることが確認された．封止可否 の境界值である圧縮比 0.66 は, 使用した試験体の仕様とそ の後の溶断条件の違いでその境界值も変わると考えられる 本実験結果より，切断面の封止可否に影響を与える因子 の一つとして，プレス圧縮比が関係していることがわかっ た.



Fig.6 Relations of press load per punch radius and press compression ratio

\section{3 水中プラズマ溶断条件の検討}

水中プラズマ溶断条件の検討を目的に，封止が可能な圧 縮比でプレスした試験体を用いて，水中プラズマ溶断実験 を行った．Fig.7 に実験の概略図を示す．試験体のプレス荷 重/パンチ半径はプレス圧縮比 0.56 狙いの $16.3 \mathrm{kN} / \mathrm{mm}$ とし た. 水中切断実験に用いたプラズマ装置は, HiFocus 600i neo（小池酸素工業製：定格出力 $600 \mathrm{~A}-200 \mathrm{~V}$ ) である. プ ラズマトーチは下向きで，精製水で満たした水槽内の水 深100 mm に試験体を水平に固定した。

プラズマ溶断実験では切断面を溶着物で塞ぎやすくする

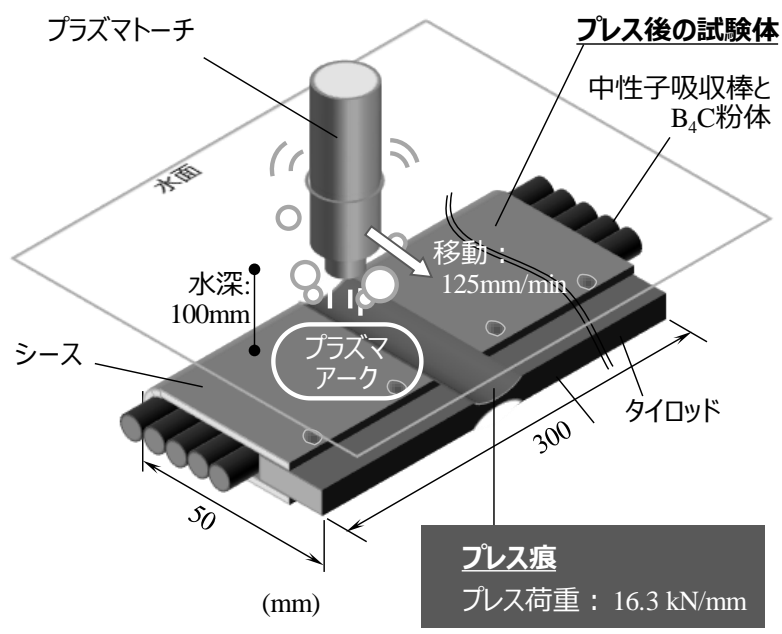

Fig.7 Schematic of underwater plasma cutting 
Table 1 Test piece of after underwater plasma cutting

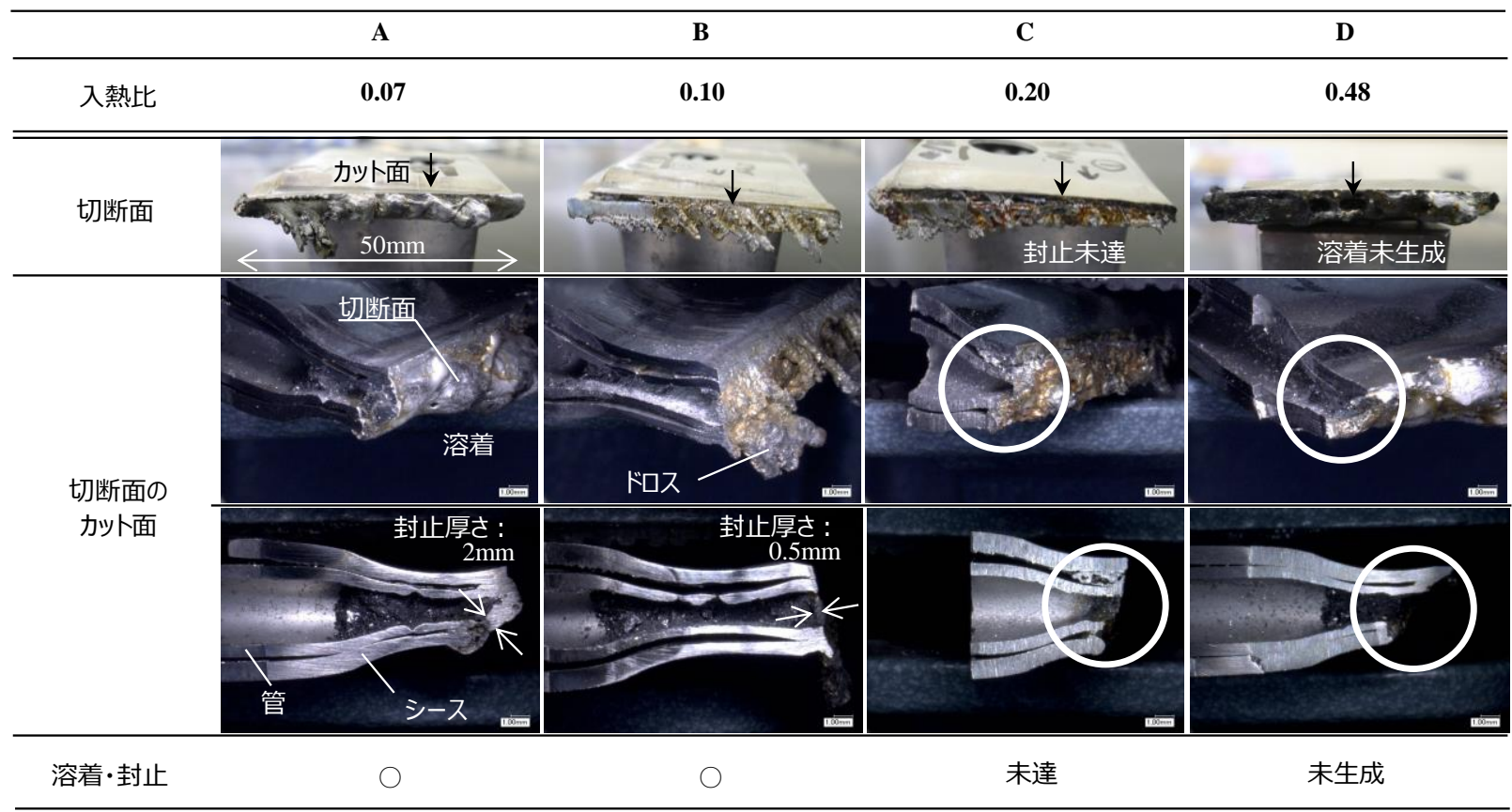

ことを目的に，一般のプラズマ加工速度より遅い速度で溶 断することにし，その移動速度に合わせて入熱量も単位時 間当たりの比を小さくした条件設定とした．理由は，移動 速度を遅くし, 且つ入熱量を小さくすることでアークの熱 で溶けた溶融物が周囲の水で泠却され, そのまま切断箇所 に留まって溶着しやすくするのを促すためである.

一般に板厚 $8 \mathrm{~mm}$ 程度のステンレス板を水中プラズマ切 断するときの移動速度はおよそ $1000 \mathrm{~mm} / \mathrm{min}$ 前後である. 溶融したステンレス材を切断面に溶着させやすいように, プラズマトーチ移動速度は一般の速度に比べ $1 / 8$ 倍の 125 $\mathrm{mm} / \mathrm{min}$ とした.

プラズマ溶断の入熱量はトーチ移動速度に合わせて一般 の入熱量より $1 / 10$ 前後に小さくした 4 条件 $(\mathrm{A} \sim \mathrm{D}$ 条件 $)$ で，一般の入熱量を 1 としたときの入熱比は $\mathrm{A}$ 条件 0.07 , B 条件 $0.10, \mathrm{C}$ 条件 $0.20, \mathrm{D}$ 条件 0.48 である.

プラズマ溶断したときの結果を Table 1 に示す. A, B の 条件では切断面は溶着物で覆われていることが観察される。 $\mathrm{A}$ 条件による溶着物の厚みは約 $2 \mathrm{~mm}, \mathrm{~B}$ 条件による溶着物 の厚みは約 $0.5 \mathrm{~mm}$ であった. $\mathrm{C}$ 条件では切断面の大部分は 溶着物で塞がれているように見えるが, 部分的に外径 1〜2 $\mathrm{mm}$ の穴が空いており溶着物で塞ぎきれておらず封止が未 達成であった。 D 条件の切断面は中性子吸収棒管の穴が暴 露されており，ステンレス材などが溶着していない様子が 確認され溶着物が未生成であった. 入熱比が $\mathrm{A}, \mathrm{B}$ 条件よ り大きい C, D 条件の入熱比 $0.20 \sim 0.48$ の範囲では切断面 の内部が暴露されており, $\mathrm{B}_{4} \mathrm{C}$ 粉体の拡散を防ぐことが困 難な条件と思われる。一方, 入熱比が小さい A, B 条件は いずれも切断面を溶着物で塞ぐことができたが，入熱比が 小さい $\mathrm{A}$ 条件の方が $\mathrm{B}$ 条件よりも封止面の厚みが大きくな った.したがって, 入熱量を小さくするほじ封止しやすく, 封止面の厚みも増すと思われる. 移動速度を同じ条件で, さらに入熱比を小さくした場合は試験体の裏面まで溶融で
きず，試験体の切断が困難になる。この場合，移動速度を さらに遅くすることで試験体の切断が可能となるが, 移動 速度の小ささは解体作業時間に影響を与えることになる. したがって，プラズマ溶断の適正条件は最終的に作業時間 を考慮して設定されると考えられる.

以上の結果から，プレス条件および水中プラズマ条件を 組み合わせることで, 切断しながら管内部を暴露させずに 溶着できる適正条件が得られることがわかった。本実験に 用いた試験体の仕様では，プレス条件は圧縮比 0.66 以下, 水中プラズマ条件は入熱比 0.1 以下が好ましいと思われる.

\section{$4 \mathrm{~B}_{4} \mathrm{C}$ 粉体の水中拡散防止効果の検討}

\section{1 試験体}

前章で得られた切断条件を基本に，短冊切断した際の水 中に拡散する $\mathrm{B}_{4} \mathrm{C}$ 粉体の拡散防止効果について定量評価す る実験を行った。実験に用いた試験体は実際の制御棒と同 数の中性子吸収棒を組込み製作した. Fig.8 にプレス後の試 験体を示す. 中性子吸収棒は実際の制御棒に用いる未使用 品を用い, その $\mathrm{B}_{4} \mathrm{C}$ 紛体の充填率は $70 \%$ あるる. 試験体

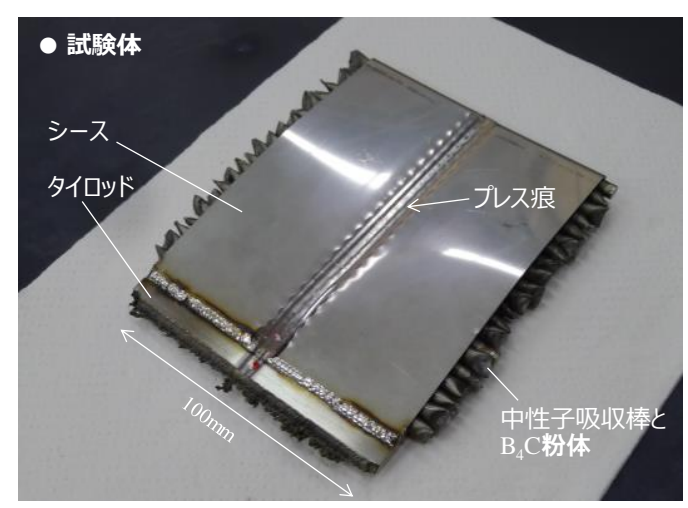

Fig.8 Test piece after press working 
Table 2 Underwater plasma cutting parameters

\begin{tabular}{|c|c|c|}
\hline 条件 & 実験概略図 & 実験の様子 \\
\hline ·試験体：垂直姿勢 & & \\
\hline •トーチ : 横向き & & \\
\hline $\begin{array}{l}\text { ·水槽 : } \\
500 \times 300 \times 430 \mathrm{~mm}\end{array}$ & & \\
\hline ·水 : 精製水，56L & & \\
\hline ·水深 : $200 \mathrm{~mm}$ & & \\
\hline -入熱比 : 0.08 & & \\
\hline $\begin{array}{l}\text { •プラズマガス： } \\
\text { Ar 4: } \mathrm{H}_{2} 1\end{array}$ & & \\
\hline -切断速度 : $80 \mathrm{~mm} / \mathrm{min}$ & & \\
\hline
\end{tabular}

の長さは $100 \mathrm{~mm}$ とし,その両端はプレス加工を施し, 水密 のために樹脂で封止してある。その他の設計值は実際の制 御棒と同じ設計仕様で構成した。水中プラズマ溶断で切断 する箇所は，試験体一体につき一箇所とし，試験体中央に プレス圧縮比 0.56 でプレスした.

\section{2 実験条件}

Table 2 に水中プラズマ溶断の実験条件を示す. 水中プラ ズマ溶断するときの試験体の姿勢は，実際の制御棒を解体 することを想定し制御棒と同じ垂直姿勢とした。この垂直 姿勢を基本に，プラズマトーチは横向きで切断する配置に し，水槽の側面からトーチを通して固定した．プラズマト 一チ先端部分はプレス箇所と同一の高さに合わせ，水槽に 水で満たしたときの水深は $200 \mathrm{~mm}$ である. 切断実験後の $\mathrm{B}_{4} \mathrm{C}$ 粉体の拡散量を定量評価するため, 切断ごとの水質分 析ができるように, 切断一回ごとに水槽内の水を入れ替え, 切断ごとに水槽水を回収した。使用した水は工業用精製水 で水槽の水量は $56 \mathrm{~L}$ である.

試験体は垂直姿勢で，プラズマ照射を横向きにして切断 を行うため，切断箇所は上下に分かれる．切断面の上下で は重力の影響で溶着状態が異なり，通常切断面上側の溶着 量は少なく，切断面下側の溶着量は多くなりやすい，本実 験では垂直姿勢でも同じような溶着量にするため，プラズ マガスの回転方向とトーチの移動方向を合わせ，切断箇所 上下の溶着量を同程度にするように調整した。トーチ移動 速度は $80 \mathrm{~mm} / \mathrm{min}$, プラズマ照射の入熱比は 0.08 とした. プラズマガスはアルゴンと水素の混合ガスで，その体積流 量比は 4:1 である. 切断実験で発生したガスを採取するた め, 切断時に発生したガスを捕集する容器を水中内の切断 上部に設け，オフガスを採取した。試験体は 4 体でプラズ マ溶断条件は 4 体とも同一条件で行った。

\section{3 実験結果}

Fig.9 にプラズマ溶断後の試験体の外観を示す．図より, 切断ラインを挟んで上下に分かれた切断面を観察すると，
上下の切断面は溶着物で覆われており, 中性子吸収棒の内 側面と $\mathrm{B}_{4} \mathrm{C}$ 粉体が露出している様子は見られなかった。さ らに，上下の切断面の溶着物の様相も顕著な違いは見られ ず，上下面に作用する溶着量の違いを抑えていることが確 認できた．以上より，試験体を垂直姿勢で切断してもプラ ズマガスの回転方向とトーチ移動条件を整えることで，切 断箇所上下の溶着量を同程度に調整でき，切断面を溶着物 で塞ぐことができることがわかった.

4 体の同一条件で行った切断実験より，切断後の試験体 からは水分量を測定し，水中プラズマ溶断したときの水槽 水（不溶解物含む） からは $\mathrm{B}_{4} \mathrm{C}$ 粉体の拡散量を測定し，水 中プラズマ溶断時に採取したガスからはオフガス量を測定 し定量評価を行った。

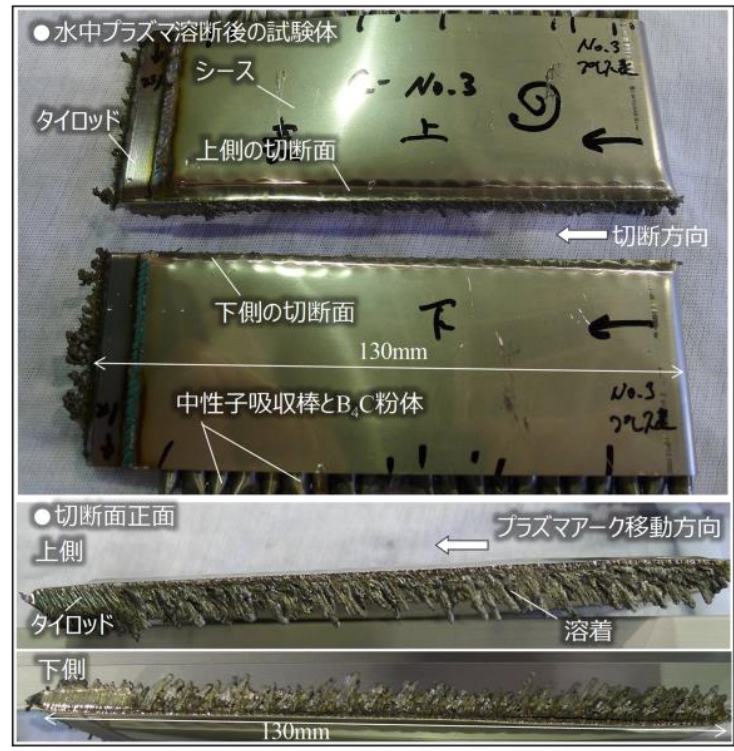

Fig.9 Test piece after the underwater Plasma cutting

\subsection{1 水分量}

水中プラズマ溶断で切断した試験体内部の水分量を測定 するため, 切断前と切断後（19 h 後）の試験体から中性子 吸収棒管（長さ $50 \mathrm{~mm}$ ）を取り出し，管内部の $\mathrm{B}_{4} \mathrm{C}$ 粉体を 
抜き取って, カールフィッシャー法で水分量を測定した. 測定器はカールフィッシャー水分計 AQ-2200A 型（平沼産 業製）を用いた。

試験体から抜き取った $\mathrm{B}_{4} \mathrm{C}$ 粉体の水分量を測定した結果 を Fig.10 に示す. 水分量は中性子吸収棒 1 本当たり（長さ $50 \mathrm{~mm}$ ）の 1 溶断面当たりの水分量である.（試験体の中性 子吸収棒の他端は, 樹脂で封止している. ) 切断前の水分量 は $0.14 \mathrm{mg} /$ 本, 水中溶断した後の水分量は $0.25 \mathrm{mg} /$ 本であ った. したがって，水中溶断で侵入した水分量はそれらの 差からおおよそ $0.11 \mathrm{mg}$ である. 実際の制御棒 1 体のブレ ードを 16 片の短冊片に解体 (制御棒 1 体から 4 つのブレー ドに分割し, それぞれ 3 回短冊切断し, 合計 16 片の短冊片 に解体）したときの制御棒 1 体当たりの水分侵入量は換算 すると $52.8 \mathrm{mg}$ であることがわかった.

収納容器に廃棄体を収めた後は, 廃棄体の水分を除去す る乾燥処理が必要となる. 乾燥処理後の収納容器内の残存 水量に関し, AESJ 報告資料[8]では収納容器内の残存水量 の定義として「“放射線分解によって発生する水素ガス濃度 が燃焼下限值を下回る” 定量值の一例として約 $2 \mathrm{~L} /$ 廃棄体 $\left(1.6 \mathrm{~m}\right.$ 角形状）以下 $\left({ }^{60} \mathrm{Co}\right.$ 放射能 $3 \times 10^{14} \mathrm{~Bq} /$ 体の場合 $) 」$ としている.

本実験手法で制御棒を解体した場合は, 制御棒 1 体に対 し長さ $1 \mathrm{~m}$ の短冊切断片 16 片が得られるため, 収納容器 （1 辺 $1.6 \mathrm{~m}$ 立方体の内側容積 1 辺 $1.5 \mathrm{~m}$ ) の占有率 $70 \%$ 以 下に収納する使用済み制御棒の総数は 50 ～80 体である. 数 量 80 体として残存水量を検討すると, Fig.10より中性子吸 収棒 $50 \mathrm{~mm}$ 当たりの切断前の水分量は $0.14 \mathrm{mg}$ であること から, 制御棒 1 体当たりの中性子吸収棒総数の長さ約 $288 \mathrm{~m}$ とすると, 収納容器に収めた廃棄体 80 体の中性子吸収棒に ある元々の水分量総数は $64.5 \mathrm{~g}$ である. 本手法で短冊切断 し中性子吸収棒に浸入した水分量は制御棒 1 体当たり 52.8 $\mathrm{mg}$ で, 収納容器に収めた廃棄体 80 体に換算すると $4.2 \mathrm{~g}$ であることから, 廃棄体 80 体の残存水量は元々の水分量と 浸入した水分量を合計した $69 \mathrm{~g}$ である.この残存水量 $69 \mathrm{~g}$

$(0.069 \mathrm{~L})$ は, 乾燥処理後の残存水量の定量值 $2 \mathrm{~L}$ 以下に 比べ $1 / 30$ と小さい. したがって, 乾燥処理への影響は生じ ないと考えられる.

本実験により中性子吸収棒の水分量が溶断前に比べ, 溶 断後は 1 溶断面当たり $0.11 \mathrm{mg}(\mathrm{n}=6)$ 上昇しており，その メカニズムについて考察してみた。水分量の実験值は 1 割 程度のバラツキ範囲の数值で安定しており, 水分浸入量 $0.11 \mathrm{mg}$ は体積にすると 1 辺 $0.5 \mathrm{~mm}$ 以下の立方体である. 切断面の封止未達, あるいは封止不良が原因で水分が上昇 したとは考えにくい，一方，水中プラズマ溶断中はアーク 発生箇所にシールドガスを噴出させアークを発生させなが ら溶断する. 原理的には溶断中の溶融固着面はシールドガ スで遮断されているため, 水が浸入しない. 仮に周囲の水 がある中で溶断した場合は本実験で得られた $0.11 \mathrm{mg}$ 程の 水分量では収まらず, 少なくても数十ミリグラム以上の水 分が浸入すると考えられる.

以上の状況から，水分が上昇したメカニズムは次に述べ る現象ではないかと推定した. 水中プラズマ溶断中は周囲 の水をシールドガスで防ぐが，シールドガス自体は水と接
している.シールドガスは周囲の水から水分を含みながら, アーク面をガスで満たす. シールドガスの一部は溶融・固 着の過程中に切断面内側に侵入する. 侵入したシールドガ スには水分が含まれており，その結果切断前に比べ水分が 上昇するに至った．以上よりシールドガスに含まれる水分 量が理由で上昇したとする仮説に関し, 本実験で得た水分 上昇量 $0.11 \mathrm{mg}$ 程の大きさは, ガスが運んだものと考えた.

水分浸入量をまとめると, 本手法ではプラズマ溶断した 場合の水分浸入量が乾燥工程で判断する乾燥後の水分量 $(2$ L) に比べ $1 / 30$ と小さく, 水分浸入に伴う乾燥処理への影 響は生じにくい，一方，切断面の封止が適切であった場合 でも, シールドガスに含まれる水分によって僅かな水分上 昇 $(0.11 \mathrm{mg})$ は, 恒久的に生じると考えられる.

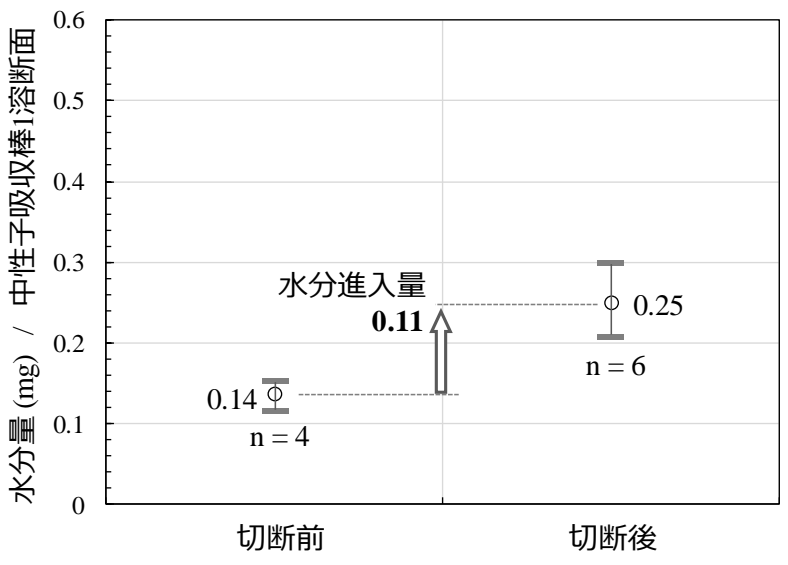

Fig.10 Moisture after underwater plasma cutting in a tube

\section{4. $3.2 \mathrm{~B}_{4} \mathrm{C}$ 粉体の水中拡散量}

水中拡散した $\mathrm{B}_{4} \mathrm{C}$ 粉体の拡散量は以下の手順で定量評価 した. $\mathrm{B}_{4} \mathrm{C}$ 粉体の拡散量の測定はプラズマ溶断で水中に溶 けた水溶液中のボロン（B）量と, 同じくプラズマ溶断で 水中に不溶解物として拡散した不溶解物中のボロン（B） を測定し，それぞれの合計したボロン（B）量から $\mathrm{B}_{4} \mathrm{C}$ 粉 体の量へと換算することで, 水中に拡散した $\mathrm{B}_{4} \mathrm{C}$ 粉体量を 求めた. 切断実験の試験体は合計 4 体で, 試験体 1 体ごと に水中に拡散した $\mathrm{B}_{4} \mathrm{C}$ 粉体量を計ることにした. 使用した 水槽水は精製水を用い, 切断の度に水槽水全量（不溶解物 含む）を回収し，回収した各々の水質を分析した．切断 1 回当たりの水槽水は $56 \mathrm{~L}$ である. 回収した水槽水はメンブ ランフィルタを通して水溶液と不溶解物に分けた.

ろ過後の不溶解物（溶着したステンレス鋼および $\mathrm{B}_{4} \mathrm{C}$ 粉 体）は切断 1 回当たり平均 $2.8 \mathrm{~g}$ であった. この值は水中プ ラズマ溶断で切断したときの切断幅 $2.0 \mathrm{~mm}$ 分に相当する 量である。

次に分離した水溶液中と不溶解物中のそれぞれのボロン （B）量を ICP-MS 定量分析で測定した. 測定に用いた ICP-MS 分析装置は7500ce（アジレント製）である. Fig.11 に切断 1 回当たりの水中に拡散した重量を示す. 水溶液中 に含まれるボロン（B）は $143 \mathrm{mg} /$ 回，不溶解物中に含まれ るボロン（B）量は $88 \mathrm{mg} /$ 回であった. その合計したボロ 
ン（B）量は $230 \mathrm{mg}$ で， $\mathrm{B}_{4} \mathrm{C}$ 粉体の重量に換算すると切断 1 回当たりに水中へ拡散した $\mathrm{B}_{4} \mathrm{C}$ 粉体は $294 \mathrm{mg}$ であること がわかった。

切断 1 回当たりの拡散量 $294 \mathrm{mg}$ より, 制御棒 1 体を 16 体の短冊片に切断したときに生じる制御棒 1 体当たりの $\mathrm{B}_{4} \mathrm{C}$ 粉体の拡散量は $3.6 \mathrm{~g}$ （短冊切断の回数 12 回）であっ た。この $\mathrm{B}_{4} \mathrm{C}$ 粉体の拡散量 $3.6 \mathrm{~g}$ は，使用済み制御棒にも ともと内在している $\mathrm{B}_{4} \mathrm{C}$ 粉体の総量約 7,500 $\mathrm{g}$ に対し, 約 $0.05 \%$ 程度と僅かな量であることがわかった。

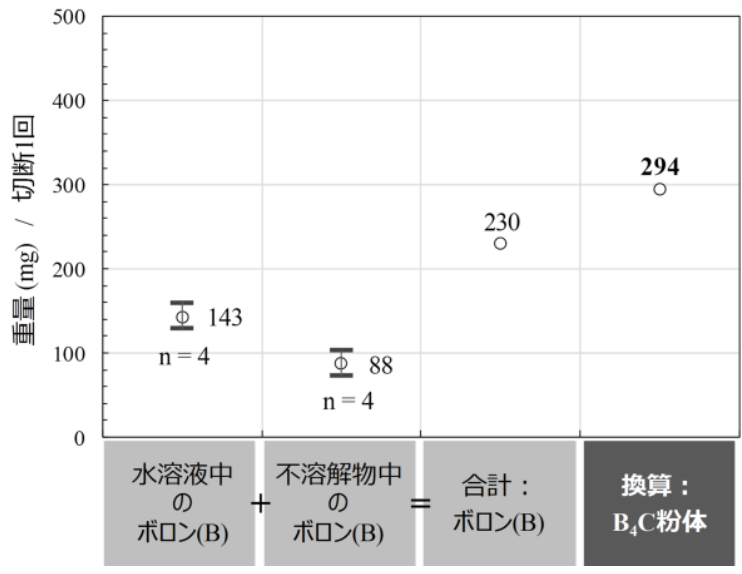

Fig.11 Emissions amount of $\mathrm{B}_{4} \mathrm{C}$ powder underwater

\subsection{3 オフガス量}

水中プラズマ溶断中に発生したオフガス量を測定するた め, Table 2 に示す捕集容器にてガスを採集したものを用い, ガスクロマトグラフ（Hitachi 製：GC3200）でガス成分の 分析を行った. 試料は 3 種類（試料 A, B, C) で, 試料 A の条件は，水中プラズマ溶断は行わずに，プラズマガス

$\left(\mathrm{Ar}+\mathrm{H}_{2}\right)$ およびシールドガス $\left(\mathrm{N}_{2}\right)$ のみを水中に放出し, 水中で捕集したガスを採取したもの．試料 B は，被加工材 としてステンレス板（板厚 $8 \mathrm{~mm}$ ）を用い，4.2 で述べた実 験条件で切断したときに発生したガスを採取したもの．試 料 C は， 4.1 と 4.2 で述べた制御棒を模擬した $\mathrm{B}_{4} \mathrm{C}$ 粉体が 充填している試験体と実験条件を用いて溶断したときに発 生したガスを採取したものである．分析するガス成分は主 要なオフガスとして水素ガス $\left(\mathrm{H}_{2}\right)$, 一酸化炭素ガス $(\mathrm{CO})$ と二酸化炭素ガス $\left(\mathrm{CO}_{2}\right)$ の 3 種類とした.

分析した結果, 水素ガス $\left(\mathrm{H}_{2}\right)$ は 3 種類の試料 (A,B,C) とも約 $30 \%$ であった．理由は，水中プラズマ溶断するため のプラズマガスには水素ガス $\left(\mathrm{H}_{2}\right)$ が用いられており，プ ラズマガスの量に占める割合が多いことが原因と考えられ， 3 種類の採取した試料からは水の分解に起因する遊離水素 量の顕著な違いは確認できなかった。

一酸化炭素 $(\mathrm{CO})$ と二酸化炭素 $\left(\mathrm{CO}_{2}\right)$ の分析した結果 を Fig.12 に示す。図より試料 A，B に比べ，試料 C には一 酸化炭素 (CO) 1,820 ppm, 二酸化炭素 $\left(\mathrm{CO}_{2}\right) 660 \mathrm{ppm}$ が 確認され，カーボンガスが発生したことがわかった.

試料 C から一酸化炭素 $(\mathrm{CO})$ および二酸化炭素 $\left(\mathrm{CO}_{2}\right)$ のカーボンガスが発生した理由は，模擬制御棒の試験体に ある $\mathrm{B}_{4} \mathrm{C}$ 粉体が原因と考えられる. 本手法で切断したとき のそのメカニズムについて以下に述べる.
まず水中プラズマ溶断は水中内で高温のプラズマガスを 照射する. 高温のガスによって水槽内の一部の水は, 酸素

$\left(\mathrm{O}_{2}\right)$ と水素 $\left(\mathrm{H}_{2}\right)$ に分解される. プレスで圧縮した切断 箇所には切断代 2 3 mm の場合約 $0.3 \sim 0.4 \mathrm{~g}$ の $\mathrm{B}_{4} \mathrm{C}$ 粉体が あり，切断箇所を溶断していくと切断箇所にある $\mathrm{B}_{4} \mathrm{C}$ 粉体 も同様の熱でボロン（B）と炭素（C）に分解する．ボロン （B）は安定なホウ酸 $\left(\mathrm{H}_{3} \mathrm{BO}_{3}\right)$ 一と変化し，そして水溶液 中に溶けこむ. 一方, $\mathrm{B}_{4} \mathrm{C}$ 粉体から分解した炭素 $(\mathrm{C})$ は, 水 $\left(\mathrm{H}_{2} \mathrm{O}\right)$ から分解した酸素 $\left(\mathrm{O}_{2}\right)$ と反応し一酸化炭素 $(\mathrm{CO})$ 一変化し, さらに一部の一酸化炭素 (CO) は二酸化炭素 $\left(\mathrm{CO}_{2}\right)$ へと変化するため, 切断箇所にある $\mathrm{B}_{4} \mathrm{C}$ 粉体がプ ラズマ溶断で然焼することにより一酸化炭素 $(\mathrm{CO})$ と二酸 化炭素 $\left(\mathrm{CO}_{2}\right)$ のカーボンガスが発生したと考えられる[9].

以上のメカニズムと本実験結果から，水溶液中に溶けた ボロン（B）量（Fig.11，143 mg/回）を用い $\mathrm{B}_{4} \mathrm{C}$ 粉体が燃 焼した量を換算 $(183 \mathrm{mg} /$ 回） し，分解した炭素 (C) 量 40 $\mathrm{mg} /$ 回を導く. 分解した炭素 (C) $40 \mathrm{mg}$ がすべて水中の酸 素（O）と結びついて一酸化炭素ガス（CO）へと変化した 場合, 短冊切断 1 回当たりに発生する一酸化炭素ガス $(\mathrm{CO})$ 量は約 $0.08 \mathrm{~L} /$ 回である. 制御棒一体を 16 片の短冊片に切 断すると（合計 12 回の切断回数）, 発生ガス総量は $0.9 \mathrm{~L}$ であることがわかった。

制御棒の主な素材はステンレス鋼と $\mathrm{B}_{4} \mathrm{C}$ 粉体で構成され， それぞれの素材にはカーボン（C）が含まれている．中性 子線とカーボン（C）の反応で，炭素 $14\left({ }^{14} \mathrm{C}\right)$ がある一定 の割合で生成される。炉内構造物の解体では構造物に含ま れる炭素 $14\left({ }^{14} \mathrm{C}\right)$ の切断分離後の動線とその取り扱い（回 収）について熟慮する必要がある.

本実験のオフガス結果（炭素 12）をもとに，使用済み制 御棒から分離する炭素 $14\left({ }^{14} \mathrm{C}\right)$ の動線について考察した. $\mathrm{B}_{4} \mathrm{C}$ 粉体が含まれる試料 $\mathrm{C}$ では, 試料 $\mathrm{A}$ で観察されなかっ た一酸化炭素 $(\mathrm{CO})$ が発生している。この現象は, $\mathrm{B}_{4} \mathrm{C}$ 粉 体が然焼し, ボロン（B）とカーボン（C）に分離後, その カーボン (C) が周囲の酸素 (O) と反応し, カーボンガス $\left(\mathrm{CO}, \mathrm{CO}_{2}\right)$ へと生成されたものである。一方，ステンレ ス鋼のみの試験体を用いた試料 B では, 一酸化炭素 $(\mathrm{CO})$

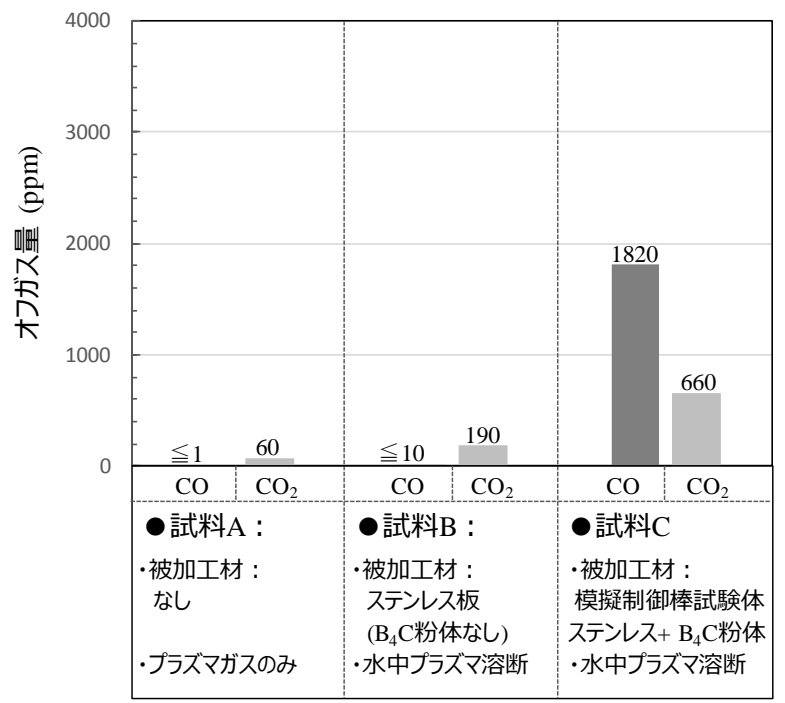

Fig.12 Off gas concentration 
の発生は僅かである。これらの結果, プラズマ溶断で発生 したカーボンガス $\left(\mathrm{CO}, \mathrm{CO}_{2}\right)$ は, 主に $\mathrm{B}_{4} \mathrm{C}$ 粉体由来のカ 一ボン（C）から構成され, ステンレス鋼由来のカーボン （C）は僅かであり，炭素 $14\left({ }^{14} \mathrm{C}\right)$ も同様である。このこ とはカーボンガス $\left(\mathrm{CO}, \mathrm{CO}_{2}\right)$ に含まれる炭素 $14\left({ }^{14} \mathrm{C}\right)$ の 動線を整理しやすく，動線を遡って検討できるのではない かと考える.

例えば，カーボンガス $\left(\mathrm{CO}, \mathrm{CO}_{2}\right)$ に関しては $\mathrm{B}_{4} \mathrm{C}$ 粉体 に焦点を当て， $\mathrm{B}_{4} \mathrm{C}$ 粉体を溶断したときの発生メカニズム とそのカーボンガス量を検討することで, カーボンガス

$\left(\mathrm{CO}, \mathrm{CO}_{2}\right)$ 発生を抑制する条件と回収技術の開発に反映 する.

一方, 4.3.2 項より本手法で切断したときの不溶解物に含 まれるステンレス鋼は約 $2.7 \mathrm{~g}, \mathrm{~B}_{4} \mathrm{C}$ 粉体は約 $0.1 \mathrm{~g}$ とステ ンレス鋼の方が 27 倍多く, 不溶解物中の炭素 $14\left({ }^{14} \mathrm{C}\right)$ は ステンレス鋼由来が多い，そのため，プラズマ溶断で生じ たカーボンガス以外の不溶解物およびヒュームに関しては, ステンレス鋼に焦点を当て，切断部位のステンレス鋼が， 不溶解物およびヒュームへと生成されるメカニズムを検討 することで，ヒューム発生を抑制する条件，あるいはそれ らの回収技術の開発に反映する.

今後は，本手法でプラズマ溶断したときの不溶解物，ヒ ユームおよびオフガスと炭素 $14\left({ }^{14} \mathrm{C}\right)$ の関係について検 討する。

\section{5 まとめ}

\section{1 結論}

使用済み制御棒の内包物（ $\mathrm{B}_{4} \mathrm{C}$ 粉体）を，水中へ拡散さ せずに短冊に切断し，効率良く収納できる技術開発（収納 容器 1 個当たり $50 \sim 80$ 体の収納）を目的に, プレスと水中 プラズマ溶断を組み合わせた切断手法を検討し，実際の制 御棒と同じ垂直姿勢で水中切断したときの $\mathrm{B}_{4} \mathrm{C}$ 粉体拡散防 止の効果について以下の結論を得た.

(1) プレス圧縮比 0.66 を境に，その後の水中プラズマ溶 断による封止可否が分かれることが確認され,プレス 加工がその後のプラズマ溶断の封止性状に影響を与 えていることが明らかとなった。

（2）トーチ移動速度と単位時間当たりの入熱量を小さく （ミ1/10）することで，プラズマ溶断の切断面を溶着 物で塞ぐことができることがわかった。

(3) 本手法で短冊片に切断したときの短冊片に水分が浸 入したときの水分浸入量は，制御棒 1 体当たり 52.8 $\mathrm{mg}$ と乾燥処理に影響を与えない大きさであった.

(4) 本手法で短冊片に切断したときの水中に拡散した $\mathrm{B}_{4} \mathrm{C}$ 粉体量は，制御棒 1 体当たり $3.6 \mathrm{~g}$ で，制御棒 1 体の $\mathrm{B}_{4} \mathrm{C}$ 粉体総量 $7500 \mathrm{~g}$ に対し，0.05\%以下である ことがわかった．以上より，本手法は $\mathrm{B}_{4} \mathrm{C}$ 粉体の拡 散防止に効果があることが確認できた。

(5) 本手法で短冊片に切断したときに発生するオフガス には, $\mathrm{B}_{4} \mathrm{C}$ 粉体の燃焼によりカーボンガスが発生する ことがわかった.その発生量は制御棒 1 体当たり $0.9 \mathrm{~L}$ であった。

\section{2 今後の検討}

今後は実機制御棒（未使用品）を用いて，落下速度リミ ッタ部位の切断, 十字形断面から 4 枚のブレード板に分割 する切断，およびプレスと水中プラズマ溶断による短冊片 へ切断する通し実験を行い，本手法を用いた一貫減容処理 技術の検証実験と，炭素 $14\left({ }^{14} \mathrm{C}\right)$ の関係について評価を 行う.

\section{謝辞}

本実験に多大な協力をいただいた小池酸素工業株式会社, 並びに同社・上野等氏，他各位に対し深く御礼を申し上げ る.

\section{参考文献}

[1] 縄田康光: 原発の「40 年ルール」とその課題. 立法と調 査, 381, pp.55-66 (2016).

[2] エネルギー総合工学研究所: 平成 29 年度 原子力の利 用状況等に関する調査（海外諸国における廃止措置の 技術等の動向調査）. IAE-1717102 (2017).

https://www.meti.go.jp/meti_lib/report/H29FY/000596.pdf

[3] 原子力規制庁: 第 22 回原子力規制委員会, 資料 3, 中深 度処分等に係る規制基準等の策定について一第二種廃 棄物埋設に係る事業許可基準規則等の骨子案の事業者 との意見交換の実施一. 平成 30 年 8 月 1 日 (2018). http://www.nsr.go.jp/data/000241068.pdf

[4] Westinghouse: BWR Reactor Pressure Vessel Internals Segmentation and Packaging. DDR-0002 (2018). http://www.westinghousenuclear.com/LinkClick.aspx?filetic ket=vE9HsOOQJAc\%3D\&portalid=0.

[5] 手塚将志 他: 東京電力福島第一原子力発電所の炉内構 造物解体を想定したプラズマ切断技術による適用性試 験. JAEA-Technology 2015-047 (2016).

[6] 原子力安全基盤機構規格基準部：中性子照射を受けた オーステナイト系ステンレス鋼の補修溶接に関する技 術指針. 2005 年 8 月, JNES-SS-0502 (2005).

[7] 原子力安全基盤機構: オーステナイト系ステンレス鋼 SUS316L 高温応力-ひずみ曲線例. 平成 20 年度 照射誘 起応力腐食割れ（IASCC）評価技術に関する報告書. 平 成 21 年 9 月 (2009).

[8] 日本原子力学会: 余裕深度処分対象廃棄体の製作に係 わる基本的要件, AESJ-SC-F014, pp.65-69 (2009).

[9] 永瀬文久, 上塚寛, 大友隆：炉心構成材料間の高温反応 で生成した反応相の元素分析. JAERI-Research 95-085 (1995). 